$\mathbb{T}$ periodica polytechnica

Chemical Engineering

$51 / 2(2007) 45+51$

doi: 10.3311/pp.ch.2007-2.07

web: http://www.pp.bme.hu/ch

(C) Periodica Polytechnica 2007

RESEARCH ARTICLE

\section{Synthesis and molecular recognition studies of crown ethers}

\author{
Péter Huszthy / Tünde Tóth
}

Received 2006-10-03

\begin{abstract}
This short review summarizes the synthesis and molecular recognition studies of crown ether type macrocycles accomplished at the Institute for Organic Chemistry of Budapest University of Technology and Economics in the last few years. The research work reported here belongs to the areas of protonionizable crown ethers and chiral macrocycles.

Proton-ionizable crown ethers at higher $\mathrm{pHs}$ than their $\mathrm{pK}_{a}$ values are mostly ionized to ligand anions which increase the cation-ligand complex stability with enhancement of selectivity and avoid the need for a counter anion to accompany the cation transport or solvent extraction. The latter factor is not only advantageous from energetical point of view, but is also important when counter anions are not required to be transported.

Enantiopure chiral macrocycles have also drawn the attention of many researchers, because owing to their enantioselective complexation they are excellent candidates for effective sensors and selectors of the enantiomers of biologically important chiral compounds such as protonated primary organic amines, amino acids and the derivatives of the latters.
\end{abstract}

\section{Keywords}

molecular recognition - enantiomeric recognition · protonionizable crown ethers · chiral crown ethers · chiral stationary phases

\section{Acknowledgement}

This work was supported by the Hungarian Scientific Research Fund (OTKA K62654) and by the Ministry of Education of Hungary (Postdoctoral Fellowship PAL 11/2003).

\section{Péter Huszthy}

Department of Organic Chemistry, BME, H-1111, Budapest, Szent Gellért tér 4., Hungary

e-mail: huszthy@mail.bme.hu

\section{Tünde Tóth}

Department of Organic Chemistry, BME, H-1111, Budapest, Szent Gellért tér 4., Hungary

\section{Introduction}

Molecular recognition is a generally occurring phenomenon in nature. Examples include the storage and retrieval of genetic information by the DNA double helix, the selective binding of a subtrate by the active site of an enzyme, the antibodyantigen interactions, selective transport of metal ions by natural ionophores through different biomembranes and incorporation of the single enantiomeric forms of amino acids and sugars in metabolic pathways. The latter two examples refer to enantiomeric recognition. Enantiomeric recognition, as a special case of molecular recognition involves the discrimination between enantiomers of the guest by a chiral host. It was believed a few decades ago that molecular recognition was the result of unique properties of complex biomolecules. However, recent successes in imitating such phenomena using relatively simple synthetic compounds have demonstrated that biological behaviour can be engineered into small molecules. Crown ether type macrocycles for example offer unusual opportunities for the study of molecular recognition. These kinds of studies are not only important, because we can get deeper insight and understandig of molecular recognition in the living organisms, but also, because as a result of these studies we can develop new molecular sensors and selectors for practical applications.

Probably the greatest impetus was given to these studies by Pedersen who in 1967 reported the synthesis and metal ion complexation properties of a large number of polyether type macrocycles which he named crown ethers [1]. Within two decades the research which started by crown ethers developed to the field of host-guest chemistry [2] and then that of supramolecular chemistry [3].

The achievments reached in these fields were awarded by the 1987 Nobel prize in Chemistry to three prominent pioneer scientists C. J. Pedersen [4], D. J. Cram [5] and J. M. Lehn [6].

Our research activities in these fields have been focused on the synthesis and molecular recognition studies of proton-ionizable crown ethers and chiral macrocycles of the same type. 


\section{Proton-ionizable Crown Ethers}

In order for an ionophore (an ion carrier) to perform ion transport against a concentration gradient across the membrane of an aqueous source phase/ lipophilic organic membrane/ aqueous receiving phase system, it should possess a high ion-binding ability at the source phase/ membrane interface, and have a low ionbinding ability at the membrane/ receiving phase interface. The solution for this seemingly contradictory requirement is to build into the ionophore a so-called switching mechanism, which can create a strong and a weak binding state. These two states can be easily and reversibly interchanged by external forces such as redox [7], light [8], temperature [9] and $\mathrm{pH}$ [10] gradients. Proton-ionizable crown ether type ionophores possessing a $\mathrm{pH}$ switching mechanism are the subjects of intensive studies, because at higher $\mathrm{pHs}$ then their $\mathrm{pK}_{a}$ values, they are mostly ionized to ligand anions, which increase the cation-ligand complex stability with enhancement of selectivity, and avoid the need for a counter anion to accompany the cation transport or solvent extraction [10]-[14]. The latter factor is not only advantageous from energetical point of view, but is also important for practical applications in cation separations when counter anions such as chloride, nitrate and sulfate are not wanted to be transported [14].

The transport of cations by proton-ionizable crown ethers in most of the cases is $\mathrm{pH}$ dependent, so it can be turned on and off by adjusting the $\mathrm{pHs}$ of the source and receiving phases, respectively. The proton-ionizable macrocyclic ionophores should be lipophilic enough to stay in the organic membrane both in complexed and uncomplexed forms. Without lipophilic substituents no transport occures, because the ionophore distributes into the aqueous phase so that it is not available as a carrier [11].

We are interested in crown ethers in which the protonionizable moiety is part of the macroring [15]-[21]. In connection of our recent work the studies by Bradshaw and co-workers in the middle of the 1980's should be mentioned.

They prepared proton-ionizable crown ethers containing the pyridone [22] and thiopyridone [23] subcyclic units, repectively (Fig. 1).

It was shown that the $\mathrm{p} K_{a}$ value of $1 H$-pyridin-4-one $\left(\mathbf{1}, \mathrm{p} K_{a}\right.$ $=11.09[24])$ and that of $1 H$-pyridin-4-thione $\left(\mathbf{2}, \mathrm{p} K_{a}=8.3\right.$ [23]) corresponded well to the $\mathrm{p} K_{a}$ values of the crown ethers $3\left(\mathrm{p} K_{a}=10.98[22]\right)$ and $4\left(\mathrm{p} K_{a}=8.65[23]\right)$, respectively. The lipophilic analogues of the latters i.e. 5 and $\mathbf{6}$ transported potassium ions selectively by adjusting the $\mathrm{pHs}$ of the aqueous source phases 13 and 11 , respectively and applying acidic receiving phases in an aqueous source phase $/ \mathrm{CH}_{2} \mathrm{Cl}_{2}$ bulk membrane/aqueous receiving phase system. Efficient and selective transport of potassium ions could only take place when an appreciable amount of the crown ether in question was ionized at the source phase/organic phase interface [11].

In 2001 we prepared more acidic pyridono-crown ethers 7-10 by introducing electron withdrawing substituents into the pyri-

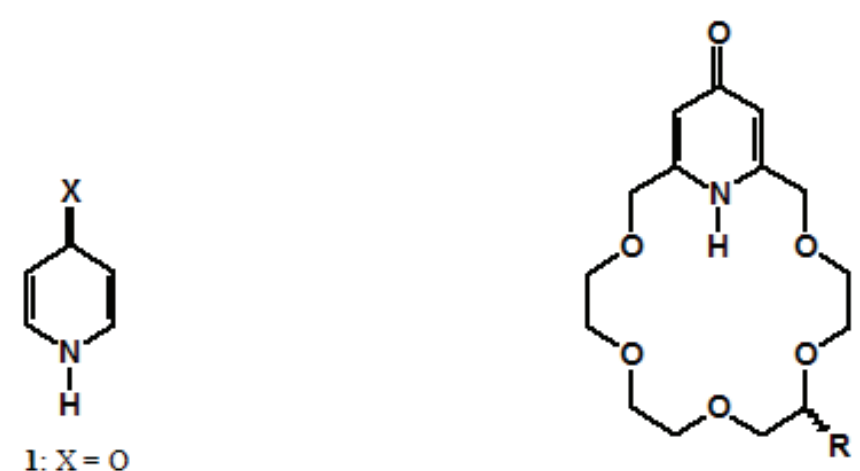

2: $\mathrm{X}=\mathrm{S}$

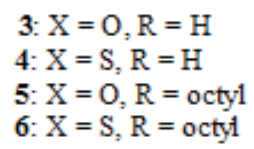

Fig. 1. Schematics of pyridono- and thiopyridono-crown ethers studied by Bradshaw and co-workers and also their parent heterocyclic subunits

done ring (Fig. 2) [15]. The $\mathrm{p} K_{a}$ values of the parent subcyclic units 3,5-dibromo- $1 H$-pyridin-4-one (11) and 3,5-dinitro- $1 H$ pyridin-4-one (12) (see Fig. 2] are 7.73 [25] and 4.56 [26], respectively.
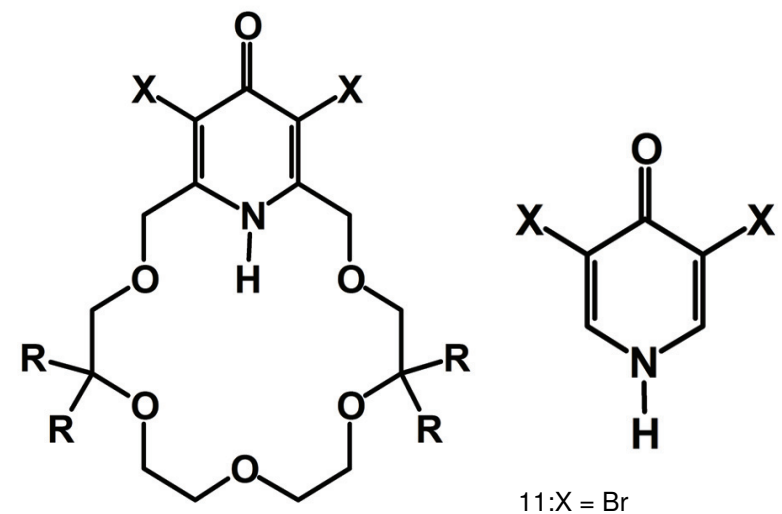

$$
\begin{aligned}
& 7: X=\mathrm{Br}, \mathrm{R}=\mathrm{H} \\
& 8: \mathrm{X}=\mathrm{NO} 2, \mathrm{R}=\mathrm{H} \\
& 9: \mathrm{X}=\mathrm{Br}, \mathrm{R}=\text { hexyl } \\
& 10: X=\mathrm{NO} 2, \mathrm{R}=\text { hexyl }
\end{aligned}
$$

$11: \mathrm{X}=\mathrm{Br}$

$12: X=N O 2$

Fig. 2. Formulas of acidic pyridono-crown ethers and their parent heterocyclic subunits

It is known that natural ionophores such as valinomycin, monensin, lasalocid, monactin, dinactin and many others are optically active compounds and their chirality plays a very important role in the selective transport of metal ions across biomembranes. As we proved by X-ray crystal analysis that protonated primary amines such as benzylammonium perchlorate $\left(\mathrm{BAHClO}_{4}\right)$ and $(R)-\alpha$-phenylethylammonium perchlorate $\left((R)-\mathrm{PEAHClO}_{4}\right)$ can also form stable complexes with the achiral pyridono-crown ether 3 (Fig. 3) [16], we decided to prepare enantiopure lipophilic pyridono- and bis-pyridono-crown ethers $(R, R, R, R)-\mathbf{1 3 -}(S, S, S, S)$-16 (see Fig. 4] [16, 18].

We extended our studies on proton-ionizable crown ethers to acridono-, thioacridono-, and substituted acridono-macrocycles 


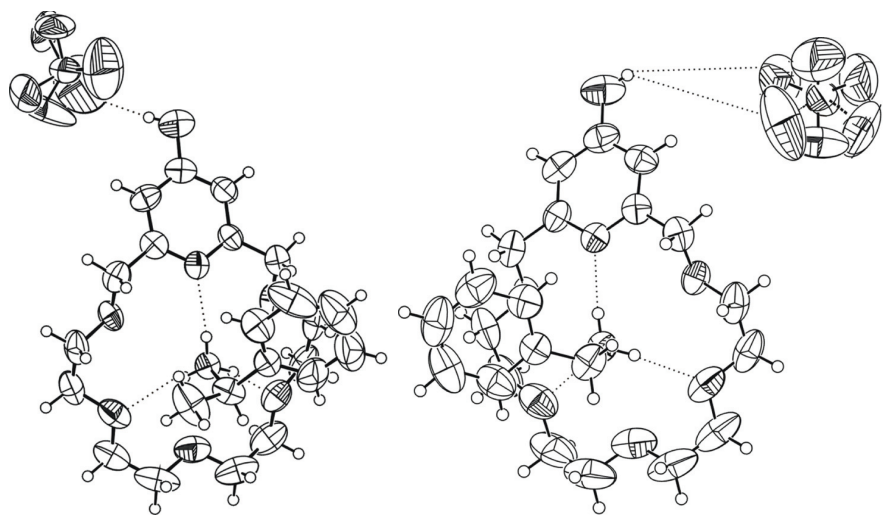

Fig. 3. X-ray structures of 3- $\mathrm{BAHClO}_{4}$ and 3-(R)-PEAHClO 4<smiles></smiles><smiles>[R]C1NC2=CC(=O)C=C(COC([R])[C@H]([R])OCCOCCO1)OCCOC([R])[C@H]([R])OC2</smiles>

$(S, S, S, S)-\mathbf{1 4}: \quad \mathrm{R}=\mathrm{CH}_{2} \mathrm{OBu}$ $(S, S, S, S)-\mathbf{1 6}: \mathrm{R}=\mathrm{CH}_{2} \mathrm{OBu}$

$(R, R, R, R)-13: \mathrm{R}=$ butyl $(\mathrm{Bu})$

$(R, R, R, R)-15: \mathrm{R}=\mathrm{Bu}$

Fig. 4. Structures of enantiopure lipophilic pyridono- and bis-pyridonocrown ethers<smiles></smiles>

17: $X=O, Y=Z=H$

18: $X=S, Y=Z=H$

19: $X=\mathrm{O}, \mathrm{Y}=\mathrm{H}, \mathrm{Z}=\mathrm{NO}_{2}$

20: $X=\mathrm{O}, \mathrm{Y}=\mathrm{NO}_{2}, \mathrm{Z}=\mathrm{Br}$

21: $X=\mathrm{O}, \mathrm{Y}=\mathrm{NO}_{2}, \mathrm{Z}=\mathrm{Cl}$

Fig. 5. Schematics of acridono-, thioacridono-, and substituted acridonomacrocycles

(Fig. 5] [17, 27]. It was shown by spectrophotometric measurements that introduction of electron withdrawing substituents into the aromatic rings of acridono-crown ethers decreased the $\mathrm{pK}_{a}$ values of the ligands to a great extent [20].

Circular dicroism (CD) spectroscopic measurements indicated that the fairly acidic proton-ionizable acridono-crown ether 21 forms a complex with $\alpha$-(1-naphthyl)ethylamine (1NEA) [19].

We also proved by X-ray crystallography that acridono-crown ethers 17, 19, 20 and 21 form very stable complexes with a molecule of water. The water molecule is fixed by strong tripo-

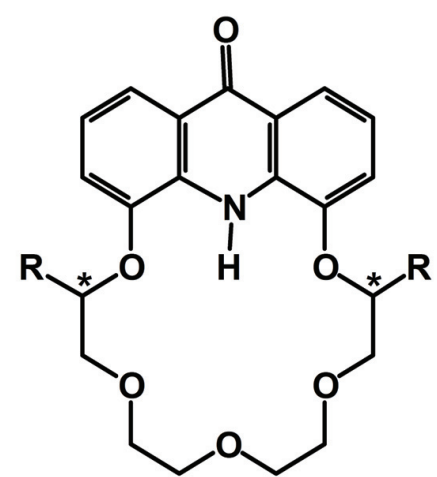

$(R, R)-22: \mathrm{R}=\mathrm{Me}$

$(R, R, R, R)-23: \mathrm{R}=i \mathrm{Bu}$

Fig. 6. Structures of enantiopure acridono-crown ethers

dal hydrogen bonds involving the $\mathrm{N}-\mathrm{H}$ proton of the heterocyclic subunit and two alternate oxygen atoms of the macroring [17].

Enantiopure dimethyl- and diisobutyl-substituted acridono18-crown-6 ethers $(R, R)-\mathbf{2 2}$ and $(R, R)-\mathbf{2 3}$ (see Fig. 6) were also prepared. The latter compounds bind selectively lead (II) cations as demonstrated by CD measurements [19].<smiles>[R4]C1OCCOC[C@@]([R1])(C)O[C@@H]([R4])[C@@H]([R4])OP(=O)(O)O1</smiles>

$$
\begin{aligned}
& \text { 24: } \mathrm{n}=1, \mathrm{R}^{1}=\mathrm{R}^{2}=\mathrm{R}^{3}=\mathrm{H} \\
& \text { rac-25: } \mathrm{n}=1, \mathrm{R}^{1}=\text { octyl, } \mathrm{R}^{2}=\mathrm{R}^{3}=\mathrm{H} \\
& \text { 26: } \mathrm{n}=2, \mathrm{R}^{1}=\mathrm{R}^{2}=\mathrm{R}^{3}=\mathrm{H} \\
& \text { rac-27: } \mathrm{n}=2, \mathrm{R}^{1}=\text { octyl, } \mathrm{R}^{2}=\mathrm{R}^{3}=\mathrm{H} \\
& \text { rac-28: } \mathrm{n}=2, \mathrm{R}^{1}=\text { decyl, } \mathrm{R}^{2}=\mathrm{R}^{3}=\mathrm{H} \\
& \text { rac-29: } \mathrm{n}=2, \mathrm{R}^{1}=\text { hexadecyl, } \mathrm{R}^{2}=\mathrm{R}^{3}=\mathrm{H} \\
& (S, S)-30: \mathrm{n}=1, \mathrm{R}^{1}=\mathrm{R}^{2}=\mathrm{H}, \mathrm{R}^{3}=i \mathrm{Bu} \\
& (S, S)-31: \mathrm{n}=2, \mathrm{R}^{1}=\mathrm{R}^{2}=\mathrm{H}, \mathrm{R}^{3}=\mathrm{Me} \\
& (S, S)-32: \mathrm{n}=2, \mathrm{R}^{1}=\mathrm{R}^{2}=\mathrm{H}, \mathrm{R}^{3}=\mathrm{Me} \\
& (S, S)-33: \mathrm{n}=2, \mathrm{R}^{1}=\mathrm{R}^{3}=\mathrm{H}, \mathrm{R}^{2}=i \mathrm{Bu} \\
& (S, S)-34: \mathrm{n}=2, \mathrm{R}^{1}=\mathrm{R}^{2}=\mathrm{H}, \mathrm{R}^{3}=i \mathrm{Bu} \\
& (S, S)-35: \mathrm{n}=2, \mathrm{R}^{1}=\mathrm{R}^{3}=\mathrm{H}, \mathrm{R}^{2}=\text { octyl } \\
& (S, S)-36: \mathrm{n}=2, \mathrm{R}^{1}=\mathrm{R}^{2}=\mathrm{H}, \mathrm{R}^{3}=\text { octyl }
\end{aligned}
$$

Fig. 7. Structures of crown ethers containing a dialkylhydrogenphosphate moiety

The acridono-18-crown-6 ethers seem to have several advantageous features compared to their pyridono analogues. The acridone tricyclic unit makes the 18-crown-6 ether framework more rigid conferring higher selectivity in the molecular recognition process. Acridone derivatives have crystallinity, attractive coloration and strong fluorescence [7]. The latter two factors have immense importance in their applications as optical sensors, because the complexation can be studied by the very 
sensitive, simple and reliable photophysical methods.

There is always a great desire to prepare proton-ionizable macrocycles with $\mathrm{pK}_{a}$ values that would allow the transport of cations at relatively low source phase $\mathrm{pH}$ values. These more acidic pH-switched ligands could also be used to transport some of the heavy metal cations, ammonium ions and protonated organic primary amines.

Two decades ago Bradshaw and co-workers synthetized crown ethers containing a dialkylhydrogenphosphate moiety 24 rac-29 (see Fig. 7) [28] which have $\mathrm{pK}_{a}$ values about 4 determined in a $70 \%$ dioxane $-30 \%$ water mixture [29]. The latter ligands were either achiral: $\mathbf{2 4}$ and $\mathbf{2 6}$ or racemic: rac-25, rac27, rac-28, rac-29 [28].

The lipophilic macrocycles rac-25, rac-27, rac-28, rac29 showed an appreciable transport of alkali, alkaline-earth and several transition metal cations in an aqueous source phase $/ \mathrm{CH}_{2} \mathrm{Cl}_{2}$ bulk membrane/aqueous receiving phase system [29]. Very recently we prepared several enantiopure protonionizable macrocycles containing the dialkylhydrogenphosphate moiety $((S, S)$-30-( $S, S)$-36) (see Fig. 7] [21].

The complexation and transport studies of these fairly acidic new proton-ionizable enantiopure macrocycles with metal cations and also with the enantiomers of chiral organic amines are in progress.

\section{Chiral Crown Ethers}

Since the pioneering work of Cram and co-workers who prepared the first optically active crown ethers containing the binaphthyl moiety as the chiral unit in the early 1970's [30], a large number of different types of chiral macrocyclic host molecules have been synthetized and studied for enantiomeric recognition of chiral guests. Most of these works have been reviewed [31][33].

In the last few years our research in this area has been focused on the synthesis of enantiopure crown ethers containing heterocyclic (pyridine [16, 18], [34]-[40], acridine [41][43] and phenazine [39, 41], [44]-[48]) subunits and their enantiomeric recognition with chiral protonated primary aralkyl amines, amino acids and their derivatives.

From the point of view of our recent studies, the earlier research on chiral pyridino-18-crown-6 ether type macrocycles carried out in Bradshaw's laboratory should be mentioned [49]. Bradshaw and co-workers showed that the main factors governing enantiomeric recognition of chiral protonated primary aralkyl amines by chiral pyridino-18-crown-6 ethers are as follows: a.) The pyridino-hosts and the protonated amine guests should form stable complexes. The two intermolecular non-covalent attractive forces which hold together the heterochiral $[(R, R)$-host/( $S)$-guest or $(S, S)$-host/( $R)$-guest $]$ and homochiral [ $(R, R)$-host/ $(R)$-guest or $(S, S)$-host/( $S)$-guest $]$ diastereomeric complexes are from one hand the tripod-like hydrogen bond involving the pyridine nitrogen and two alternate macroring oxygens of the host and the three ammonium protons of the guest, repectively, and from the other hand the $\pi-\pi$ stacking between the two aromatic moieties of the host and guest, repectively. b.) The degree of enantiomeric recognition (enantioselectivity) depends mainly on the difference in steric repulsions of the two diastereomeric complexes caused by the bulky substituents at the chiral centers of the host and certain hydrogen atoms of the guests, repectively. The larger the substituents at the chiral centers the higher the enantioselectivity. c.) The conformation of the host should be rigid. The rigid host which is preorganized to accommodate one enantiomer of the guest can only adjust its conformation to fit the other enantiomer by using up a lot of energy which decreases the stability of the other diastereomeric complex. d.) Solvents and mixtures of solvents can also effect enantioselectivity [49].

We have prepared several enantiopure pyridino-crown ethers containing suitable side chains (see Fig. 8) which made possible to attach them to solid supports such as silica gel [34, 35, 37, 40] and polymer resin [36].
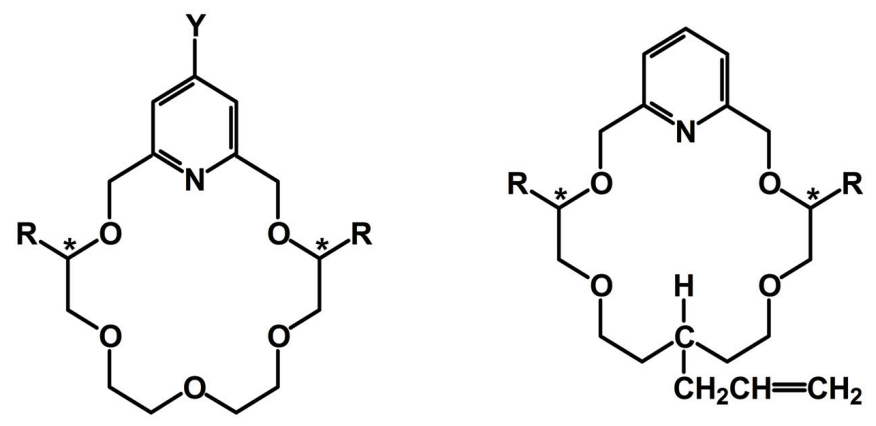
$(S, S)-37: \mathrm{R}=\mathrm{Me}$
$(S, S)$-40: $\mathrm{R}=\mathrm{Me}, \mathrm{Y}=\mathrm{OCH}_{2} \mathrm{CONHCH}_{2} \mathrm{CH}=\mathrm{CH}_{2}$
$(S, S)-38: \mathrm{R}=i \mathrm{Bu}$
$(S, S)-\mathbf{4 1}: \mathrm{R}=\mathrm{Me}, \mathrm{Y}=\mathrm{OCH}_{2} \mathrm{COOH}$
$(R, R)-38: \mathrm{R}=t \mathrm{Bu}$
$(S, S)-42: \mathrm{R}=i \mathrm{Bu}, \mathrm{Y}=\mathrm{OCH}_{2} \mathrm{COOH}$
$(R, R)$-43: $\mathrm{R}=t \mathrm{Bu}, \mathrm{Y}=\mathrm{OCH}_{2} \mathrm{COOH}$
$(S, S)$-44: $\mathrm{R}=\mathrm{Me}, \mathrm{Y}=\mathrm{O}\left(\mathrm{CH}_{2}\right)_{3} \mathrm{OH}$
$(R, R)$-45: $\mathrm{R}=t \mathrm{Bu}, \mathrm{Y}=\mathrm{OCH}_{2} \mathrm{CH}=\mathrm{CH}_{2}$

Fig. 8. Enantiopure pyridino-crown ethers containing side chains

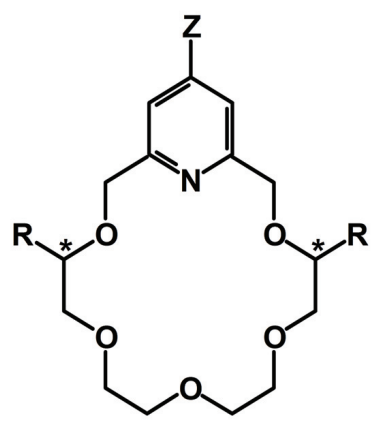
$(R, R)$-CSP-46: $\mathrm{R}=t \mathrm{Bu}, \mathrm{Z}=\mathrm{O}\left(\mathrm{CH}_{2}\right)_{3} \mathrm{Si}$
$+\quad(R, R)$-CSP-47: $\mathrm{R}=t \mathrm{Bu}, \mathrm{Z}=\mathrm{OCH}_{2} \mathrm{CONH}\left(\mathrm{CH}_{2}\right)_{3} \mathrm{Si}$
$(S, S)$-CSP-48 : R= Me, $\mathrm{Z}=\mathrm{OCH}_{2} \mathrm{CONH}\left(\mathrm{CH}_{2}\right)_{3} \mathrm{Si}$

Fig. 9. Chiral stationary phases (CSPs) used for enantioseparation by column chromatography

Our effort in this respect were aimed at obtaining chiral stationary phases (CSPs) which by enantioselective complexation 


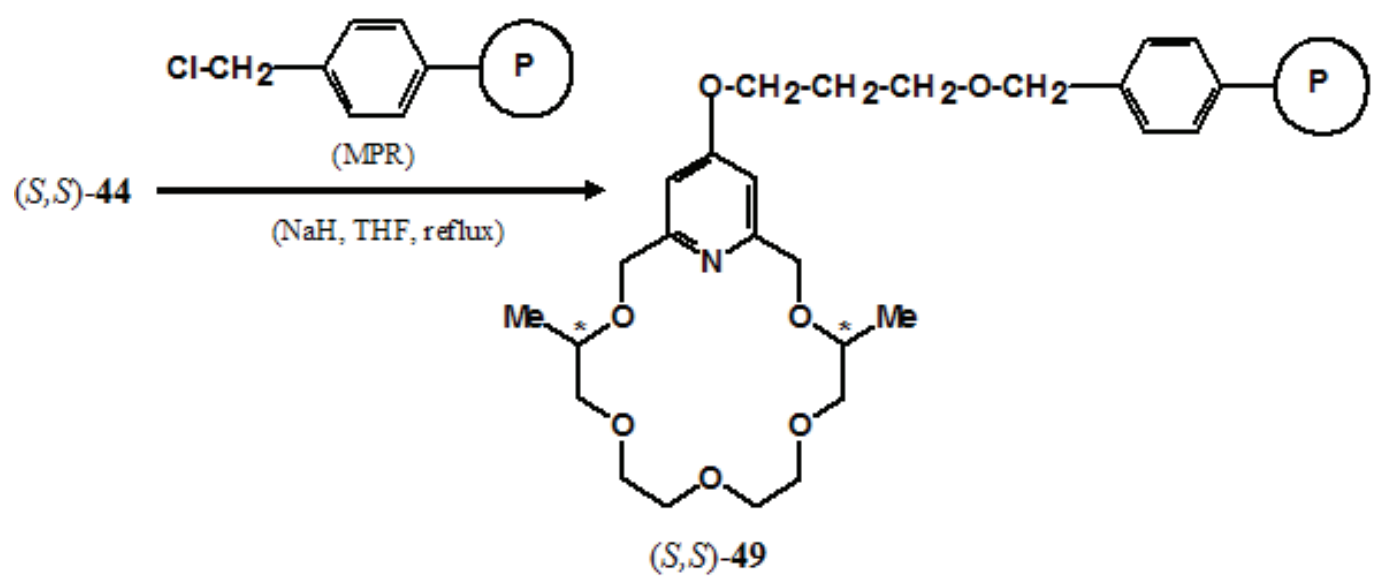

Fig. 10. Preparation of Merrifield resin-bound chiral crown ether

could separate protonated primary aralkyl amines, amino acids and their derivates using column chromathography.

The enantiomeric discrimination of the parent chiral crown ethers shown in Fig. 8 toward protonated aralkyl amines and amino acid derivatives containing aromatic moieties had been studied by ${ }^{1} \mathrm{H}$ NMR [35] and CD [39] spectroscopies before their attachment to solid supports.

In the last few years we prepared three CSP-s at the Institute for Organic Chemistry, Budapest University of Technology and Economics (BUTE) (see Fig. 9). In 1999 we attached allyloxysubstituted pyridino-crown $(R, R)-\mathbf{4 5}$ by starting with a highly regioselective hydrosilylation with triethoxysilane in the presence of a Pt-catalyst followed by heating the triethoxysilylpropyloxy derivative with ordinary silica gel in toluene to obtain $(R, R)$-CSP-46 [34].

Chiral stationary phase $(R, R)$-CSP-46 resolved racemic $\alpha$ (1-naphthyl)ethylamine hydrogenperchlorate $\left(1-\mathrm{NEAHClO}_{4}\right)$, $\alpha$-phenylethylamine hydrogenperchlorate ( $\left.\mathrm{PEAHClO}_{4}\right)$, methyl phenylalaninate hydrogenperchlorate $\left(\mathrm{MPHEHClO}_{4}\right)$ and methyl phenylglicinate hydrogenperchlorate ( $\left.\mathrm{MPGLYHClO}_{4}\right)$ by chromatography with great efficiency [34, 38].

In 2000 we prepared $(R, R)$-CSP-47 starting from $(R, R)-\mathbf{4 3}$. The latter acid was treated with

(3-aminopropyl)trimethoxysilane in the presence of $N, N^{\prime}$ dicyclohexylcarbodiimide, then the amide derivative of the pyridino-crown ether containing the trimethoxysilyl end group was heated the HPLC quality silica gel in toluene to give $(R, R)$ CSP-47 [37]. The latter CSP gave base-line enantiomeric separation for racemic 1-NEAHClO 4 and $\mathrm{PEAHClO}_{4}$ [37].

Very recently we prepared $(S, S)$-CSP-48 starting from $(S, S)$-40. The latter dimethyl-substituted pyridino-crown ether containing a side chain with terminal double bound was reacted first with triethoxysilane in the presence of a Pt-catalyst then the triethoxysilyl derivative so obtained was heated with spherical HPLC quality silica gel to get $(S, S)$-CSP-48 [40]. Chiral stationary phase $(S, S)$-CSP-48 gave base-line enantioseparation for racemic 1-NEAHClO $4, \alpha$-(2-naphthyl)ethylamine hydrogenperchlorate, tryptophan, phenylalanine, tyrosine, $S$ - benzyl-homocysteine, $\varepsilon-N$-benzyloxycarbonyl-lysine and $O$ benzyl-serine [40]. The dimethyl-substituted pyridino-crown ether derivative $(S, S)$-44 containing a side chain with terminal hydroxyl group was attached to Merrifield polymer resin (MPR). Hydroxy derivative $(S, S)-\mathbf{4 4}$ was heated with MPR in the presence of a strong base NaH in THF to obtain polymerbound chiral crown $(S, S) \mathbf{- 4 9}$ (see Fig. 10] [36].

The Merrifield resin-bound chiral crown ether $(S, S)-\mathbf{4 9}$ separated the enantiomers of racemic $1-\mathrm{NEAHClO}_{4}$ with less efficiency than its silica gel based analogue ( $S, S)$-CSP-48 [36, 40].

We also prepared enantiopure crown ethers containing acridine [41] and phenazine [41, 45] subcyclic units (see Fig. 11]. These ligands had been expected to show high enantiomeric recognition toward protonated aralkyl amines and amino acid derivatives, because of their extended $\pi$ systems and high conformational rigidity [41].

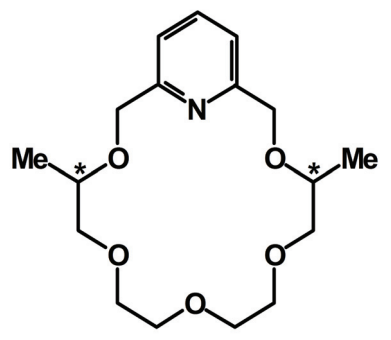

$(R, R)-50: \mathrm{X}=\mathrm{CH}$

$(R, R)-51: \mathrm{X}=\mathrm{N}$

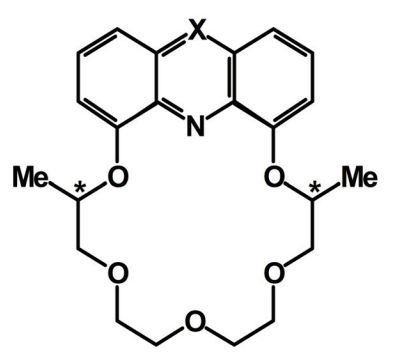

$(S, S)-52$
Fig. 11. Schematics of dimethyl-substituted acridino-, phenazino- and pyridino-18-crown-6 ethers

Luminescence spectroscopic studies showed that acridinocrown ether $(R, R)-\mathbf{5 0}$ had higher enantioselectivity toward both 1-NEAHClO 4 and $\mathrm{PEAHClO}_{4}$ than that of the pyridino analogue $(S, S)-52$ [42, 49].

Luminescence spectroscopic studies also confirmed that phenazino-crown ether $(R, R)-\mathbf{5 1}$ had lower enantioselectivity toward both 1-NEAHClO 4 and $\mathrm{PEAHClO}_{4}$ than that of the pyridino analogue $(S, S)-52$ [46, 49].

The above results encouraged us to prepare an enantiop- 
ure dimethyl-substituted acridino-18-crown-6 ether with suitable side chain which made possible to attach it to spherical HPLC silica gel to get a new CSP [50].

\section{References}

1 Pedersen CJ, Cyclic Poliethers and Their Complexes with Metal Salts, J. Am. Chem. Soc 89 (1967), 7017-7036.

2 Vögtle F, Weber E, Host-Guest Complex Chemistry: Macrocycles, Spinger Verlag, Heidelberg, 1985.

3 Steed JW, Atwood JL, Supramolecular Chemistry, John Wiley \& Sons Ltd, New York, 2000.

4 Pedersen CJ, Die Entdeckung der Kronenether (Nobel-Vortrag), Angew. Chem. 100 (1988), 1053-1059.

5 Cram DJ, Von molekularen Wirten und Gästen sowie ihren Komplexen (Nobel-Vortrag), Angew. Chem. 100 (1988), 1041-1052.

6 Lehn J-M, Supramolekulare Chemie-Moleküle, Übermoleküle und molekulare Funktionseinheiten (Nobel-Vortrag), Angew. Chem. 100 (1988), 91-116.

7 Chen Z, Echengoyen L, Crown Compounds: Toward Future Applications: Redox-Active Polyether Ligands: Toward Metal Ion Isotopic Separation, Cooper S R Ed. VHC, New York, 1992.

8 Shinkai S, Switch-functionalized Systems in Biomimetic Chemistry, Pure Appl. Chem. 59 (1987), 425-430.

9 Shinkai S, Torigoe K, Manabe O, Kajikama T, Temperature Regulation of Crown-mediated Ion Transport Through Polymer/Liquid Crystal Composite Membranes. Remarkable Transport Ability of Fluorocarbon-containing Crown Ethers, J. Am. Chem. Soc. 109 (1987), 4458-4464.

10 Mcdaniel CW, Bradshaw JS, Izatt RM, Proton-ionizable Crown Ethers.: A Short Review, Heterocycles 30 (1990), 665-706.

11 Bradshaw JS, Izatt RM, Huszthy P, Nakatsuji Y, Biernat JF, Kojama H, McDaniel CW, Wood SA, Nielsen RB, Lindh GC, Bruening RL, Lamb JD, Christensen JJ, The Design of Proton-ionizable Macrocyclic Ligands for Selective Cation Transport in Liquid Membrane Systems, Studies in Organic Chemistry 31 (1987), 553-560.

12 Bartsch RA, Effect of Structural Variation Within Proton-ionizable Crown Ethers Upon the Selectivity and Efficiency of Solvent Extraction of Alkali Metal and Alkaline Earth Cations, Solvent Extraction and Ion Exchange 7 (1989), 829-854.

13 Bradshaw JS, Twenty-five Years of Crowing Around: Synthesis of Crown Ethers at Brigham Young University, J. Incl. Phenom. Mol. Recogn. Chem. 29 (1997), 221-246.

14 Bartsch RA, Metal Ion Separations with Proton-ionizable Lariat Ethers, ACS Symposium Series 716 (1999), 146-155.

15 Huszthy P, Kertész J, Bradshaw JS, Izatt RM, Redd JT, Synthesis of New Proton-ionizable Crown Ether Compounds Containing Substituted $1 \mathrm{H}$ pyridin-4-one Subcyclic Units, J. Heterocyclic Chem. 38 (2001), 1259-1264.

16 Gerencsér J, Báthori N, Czugler M, Huszthy P, Nógrádi M, Synthesis of New Optically Active Pyridino- and Pyridono-18-crown-6 Type Ligands Containing Four Lipophilic Chains, Tetrahedron:Asymmetry 14 (2003), 2803-2811.

17 Huszthy P, Vermes B, Báthori N, Czugler M, Synthesis and X-ray Crystallographic Studies of Novel Proton-ionizable Nitro- and Halogensubstituated Acridono-18-crown-6 Chromo- and fluorogenic Ionophores, Tetrahedron 59 (2003), 9371-9377.

18 Gerencsér J, Huszthy P, Nógrádi M, Synthesis of New Optically Active Bis-pyridino- and bis-pyridono-18-crown-6 Type Ligands Containing Four Lipophilic Chains Attached to the Chiral Centers by „Two-to-two” Type Macrocyclization, ARKIVOC (2004), 7-14.

19 Szalay L, Farkas V, Vass E, Hollósi M, Móczár I, Pintér Á, Huszthy $\mathbf{P}$, Synthesis and Selective Lead (II) Binding of Achiral and Enantiomerically Pure Chiral Acridono-18-crown-6 Ether Type Ligands, Tetrahedron:Asymmetry 15 (2004), 1487-1493.
20 Kádár M, Biró A, Tóth K, Vermes B, Huszthy P, Spectrophotometric Determination of the Dissociation Constants of Crown Ethers with Grafted Acridone Unit in Methanol Based on Benesi-Hildebrand Evaluation, Spectrochimica Acta Part A 62 (2005), 1032-1038.

21 Kovács I, Huszthy P, Bertha F, Sziebert D, Synthesis of New Enantiopure Proton-ionizable Crown Ethers Containing a Dialkylhydrogenphosphate Moiety, Tetrahedron:Asymmetry 17 (2006), 2538-2547.

22 Bradshaw J S, Nakatsuji Y, Huszthy P, Wilson BE, Dalley NK, Izatt RM, Proton-ionizable Crown Compounds. 3. Synthesis and Structural Studies of Macrocyclic Polyether Ligands Containing a 4-Pyridone Subcyclic Unit, J. Heterocyclic Chem. 23 (1986), 353-360.

23 Bradshaw JS, Huszthy P, Koyama H, Wood SG, Strobel SA, Davidson RB, Izatt RM, Dalley NK, Lamb JD, Christensen JJ, Protonionizable Crown Compounds. 8. Synthesis and Structural Studies of Macrocyclic Polyether Ligands Containing a 4-Thiopyridone Subcyclic Unit, J. Heterocyclic Chem. 23 (1986), 1837-1843.

24 Christensen JJ, Hansen LD, Izatt RM, Handbook of Proton-ionization, Heats and Related Thermodynamic Quantities, John Wiley \& Sons, Ltd, New York, 1976.

25 Bunting JW, Toth A, Heo CKM, Moors RG, Equilibriation of $\mathrm{N}-(2-$ cyanoethyl)pyridinium Cations with Substituted Pyridines and Acrylonitrile: A Change in Rate-determining Step in an Elab Reaction, J. Am. Chem. Soc. 112 (1990), 8878-8885.

26 Gordon A, Katritzky AR, Roy SK, Tautomeric Pyridines. Part X.: Effects of Substituents on Pyridone - Hydroxypyridine Equilibria and Pyridone Basicity, J. Chem. Soc. B. (1968), 556-561.

27 Huszthy P, Köntös Z, Vermes B, Pintér Á, Synthesis of Novel Fluorescent Acridono- and thioacridono-18-crown-6 Ligands, Tetrahedron 57 (2001), 4967-4975.

28 Bradshaw JS, Huszthy P, Izatt RM, Proton-ionizable Crown Compounds. 7. Synthesis of New Crown Compounds Containing the Dialkylhydrogenphosphate Moiety, J. Heterocyclic Chem. 23 (1986), 1673-1676.

29 Izatt RM, Lindh GC, Huszthy P, Clark GA, Buerning LR, Bradshaw J S, Christensen JJ, Proton-ionizable Crown Compounds. 18.: Comparison of Alkali Metal Transport in a $\mathrm{H}_{2} \mathrm{O}-\mathrm{CH}_{2} \mathrm{Cl}_{2}-\mathrm{H}_{2} \mathrm{O}$ Liquid Membrane System by Four Proton-ionizable Macrocycles Containing the Dialkylhydrogenphoshate Moiety, J. Incl. Phenom. Mol. Recogn. Chem. 7 (1989), 501-509.

30 Kyba EB, Koga K, Siegel MG, Cram DJ, Chiral Recognition in Molecular Complexing, J Am. Chem. Soc. 95 (1973), 2691-2693.

31 Stoddart JF, Chiral Crown Ethers in Topics in Stereochemistry (John Wiley \& Sons, ed.), Vol. 17, New York, 1988.

32 Zhang XX, Bradshaw JS, Izatt R M, Enantiomeric Recognition of Amine Compounds by Chiral Macrocyclic Receptors, Chem. Rev 97 (1997), 33133361.

33 Davis AP, Encyclopedia of Supramolecular Chemistry: Chiral Guest Recognition (Atwood JL, Steed JW, eds.), Marcel Dekker, Inc., New York, 2004.

34 Köntös Z, Huszthy P, Bradshaw JS, Izatt RM, Enantioseparation of Racemic Organic Ammonium Perchlorates by a Silica Gel Bound Optically Active Di-tert-butylpyridino-18-crown-6 Ligand, Tetrahedron:Asymmetry 10 (1999), 2087-2099.

35 Samu E, Huszthy P, Horváth G, Szöllősy Á, Neszmélyi A, Enantiomerically Pure Chiral Pyridino-crown Ethers: Synthesis and Enantioselectiv-

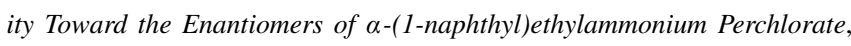
Tetrahedron:Asymmetry 10 (1999), 3615-3626.

36 Horváth G, Huszthy P, Chromatographic Enantioseparation of Racemic $\alpha$ (1-naphthyl)ethylammonium Perchlorate by a Merrifield Resin-bound Enantiomerically Pure Chiral Dimethylpyridino-18-crown-6 Ligand, Tetrahedron:Asymmetry 10 (1999), 4573-4583.

37 Horváth G, Huszthy P, Szarvas S, Szókán G, Redd JT, Bradshaw JS, Izatt RM, Preparation of a New Chiral Pyridino-Crown Ether-based Station- 
ary Phase for Enantioseparation of Racemic Primary Organic Ammonium Salts, Ind. Eng. Chem. Res. 39 (2000), 3576-3581.

38 Köntös Z, Huszthy P, Bradshaw JS, Izatt RM, Semipreparative Scale Enantioseparation of Racemic Amine and Amino Ester Hydrogenperchlorate Salts Using a Silica Gel-bound Optically Active Di-tert-butylpyridino18-crown-6 Ligand, Enantiomer 5 (2000), 561-566.

39 Farkas V, Szalay L, Vass E, Hollósi M, Horváth G, Huszthy P, Probing the Discriminating Power of Chiral Crown Hosts by CD Spectroscopy, Chirality 15 (2003), S65-S73.

40 Farkas V, Tóth T, Orosz G, Huszthy P, Hollósi M, Enantioseparation of Protonated Primary Arylalkylamines and Amino Acids Containing an Aromatic Moiety on a Pyridino-crown Ether Based New Chiral Stationary Phase, Tetrahedron:Asymmetry 17 (2006), 1883-1889.

41 Huszthy P, Samu E, Vermes B, Mezey-Vándor G, Nógrádi M, Bradshaw JS, Izatt RM, Synthesis of Novel Acridino- and phenazino-18-crown6 Ligands and Their Optically Pure Dimethyl-substituted Analogues for Molecular Recognition Studies, Tetrahedron 55 (1999), 1491-1504.

42 Prodi L, Bolletta F, Monalti M, Zaccheroni N, Huszthy P, Samu E, Luminescence Signalled Enantiomeric Recognition of Chiral Organic Ammonium Ions by an Enantiomerically Pure Dimethylacridino-18-crown-6 Ligand, New J. Chem. 24 (2000), 781-785.

43 Szarvas S, Mayer Z, Huszthy P, Vermes B, Hollósi M, Chiroptical Properties of Acridino-18-crown-6 Ligands and Their Complexes with Chiral and Achiral Protonated Primary (Aralkyl) Amine Guest Molecules, Enantiomer 7 (2002), 241-249.

44 Gérczei T, Böcskei Z, Keserü GM, Samu E, Huszthy P, Enantiomeric Recognition of $\alpha$-(naphthyl)ethylammonium Perchlorate by Enantiomerically Pure Dimethyl-phenazino-18-crown-6 Ligand in Solid and Gas Phases, Tetrahedron:Asymmetry 10 (1999), 1995-2005.

45 Samu E, Huszthy P, Somogyi L, Hollósi M, Enantiomerically Pure Chiral Phenazino-crown Ethers: Synthesis, Preliminary Circular Dichroism Spectroscopic Studies and Complexes with the Enantiomers of 1-Arethyl Ammonium Salts, Tetrahedron:Asymmetry 10 (1999), 2775-2795.

46 Dolci LS, Huszthy P, Samu E, Monalti M, Prodi L, Zaccheroni N, Photophysical Characterization, Metal Ion Binding, and Enantiomeric Recognition of Chiral Ligands Containing Phenazine Fluorophore, Collect. Czech. Chem. Commun. 69 (2004), 885-896.

47 Bereczki L, Marthi K, Huszthy P, Pokol G, 18-Crown-6 Ether Complexes with Aralkylammonium Perchlorates. Thermochemical Properties, J. Therm. Anal. Cal. 78 (2004), 449-459.

48 Szarvas S, Szalay L, Vass E, Hollósi M, Samu E, Huszthy P, Chiroptical Properties of Cation Complexes of Chiral Phenazino-18-crown-6 Ether-type Hosts, Chirality 17 (2005), 345-351.

49 Izatt RM, Wang TM, Hathaway JK, Zhang XX, Curtis JC, Bradshaw JS, Zhu CY, Huszthy P, Factors Influencing Enantiomeric Recognition of Primary Alkylammonium Salts by Pyridino-18-crown-6 Type Ligands, J. Incl. Phenom. Mol. Recogn. Chem. 17 (1994), 157-175.

50 Lakatos S, Fetter J, Bertha F, Huszthy P, Tóth T, Farkas V, Orosz G, Hollósi M, Preparation of a New Acridino-18-Crown-Ether-Based Stationary Phase for Enantioseparation of Racemic Protonated Primary Aralkyl Amines, Tetrahedron (2007). doi:10.1016/j.tet.2007.09.056. 